Journal of Qualitative Criminal Justice \& Criminology

\title{
Book Review | Routledge Handbook of Green Criminology
}

Gary R. Potter ${ }^{1}$

${ }^{1}$ London South Bank University

Published on: Oct 01, 2014

DOI: 10.21428/88de04a1.094baOdo

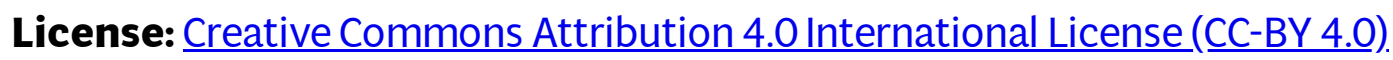


Nigel South and Avi Brisman (eds.). Routledge Handbook of Green Criminology. Routledge, 2013; 448 pp.; ISBN: 9780415678827.

The first articulation of a 'green' criminology - that is, a criminology concerned with man-made environmental harm -is usually attributed to Michael Lynch (1990) in his essay The Greening of Criminology: A perspective on the 1990s. Although not the first criminological work on environmental harm, Lynch was one of the first to argue that environmental problems in themselves, and the social harms that so often stem from them, can be seen to be legitimate criminological concerns-and that criminologists, therefore, may be well positioned to contribute to analysis and discussion of the environmental degradation that has become characteristic of late-modern, super-industrialised global society. At the time, Lynch firmly aligned this to critical and radical criminological traditions, recognising the common cause of social inequality and ecological devastation. To slightly oversimplify, those fighting social injustice and those concerned with environmental degradation share a common enemy in the unrestrained forces of global consumer capitalism, and a common cause in the resultant suffering of marginalised and powerless groups.

For much of the next two decades, green criminology remained a somewhat niche interest. Publications in this specialist area slowly began to multiply (with a special edition of Theoretical Criminology in 1998 being a particular landmark) but green criminology struggled to be taken seriously as a mainstream criminological concern. When I started teaching a specialist undergraduate course in green criminology in 2008 it was, to my knowledge, the first of its kind in England (elsewhere in the UK, a course at Queen's University, Belfast, was started by Dr John Karamichas in the same year). Selecting materials for a reading list was somewhat easy as there was so little to choose from; convincing both students and colleagues (both within and beyond my own institution) that environmental problems should be a central plank of criminological study was somewhat harder. These two observations go to the same point: green criminology simply didn't feature in major criminology textbooks, taught courses or, for that matter, conferences and was far from being accepted as belonging to the criminological mainstream.

This situation has changed significantly in recent years. A plethora of books and articles on green criminology, environmental crime, conservation criminology and related areas have come into being. The conferences of both the American and British societies of criminology now have regular green criminological streams, and specialist international conferences have taken place in the Netherlands and the UK. Many introductory criminological textbooks now include chapters on environmental crime, as do an increasing number of undergraduate criminology and criminal justice courses in Europe, North America and beyond. Importantly, criminologists from mainstream, administrative and 
realist perspectives have joined their radical, critical and idealist cousins in recognising environmental problems as a legitimate criminological focus. Like the study of white-collar, corporate and state crime, green criminology has become established within the broader criminological tent.

The Routledge Handbook of Green Criminology both reflects and continues this development. It is the first collection of its kind-a selection of commissioned contributions that begins to do justice to both the breadth of subject matter and depth of analysis that green criminology has become. It is an impressive volume -26 chapters (divided into six sections) from 36 contributors whose biographies and research represent all corners of the globe. Chapters include empirical case-studies (both problem-specific and location-based), reviews and more theoretically-driven essays. Examples and discussions cover the full range of local to global, with analyses of environmental problems including global warming, deforestation, hunting, poaching and the wildlife trade, pollution, food contamination, littering and more - although such is the range of environmental harm that could be, and increasingly is, being subject to criminological analysis, the editors do emphasise that the book's content is "representative, rather than exhaustive" (p. 19, emphasis in original).

As is usually the aim, but not always the case, in such a work, each chapter is a worthy stand-alone piece in its own right, and a chapter-by-chapter overview is beyond this review. However, there are a couple of particular points that emerge from the book as a whole that are worth highlighting here. First, there is the variety of topics dealt with. Not only are a range of harms against the environment (environmental harm as crime) covered, as suggested above, but a number of other areas where environmental issues overlap with criminological issues are also included - examples include chapters that focus wholly or partly on the way that environmental damage can be a causal factor in more 'traditional' types of crime (environmental harm as a cause of crime), be it 'the criminogenic consequences of climate change' (Hall and Farrell; chapter 7) or the 'wild west' criminality associated with the deforestation of the Amazon rainforest (Boekhout van Solinge and Kuijpers; chapter 12), and a chapter examining the potentially beneficial role of nature in rehabilitating offenders (Pretty, Wood, Bragg and Barton; chapter 11). Such varied contributions both reflect and strengthen the argument that a 'green' perspective can have a lot to contribute to criminology as a whole.

Second, the theoretical approaches seen in different chapters are noteworthy in their own right, but taken together suggest some theoretical development across green criminology more broadly. On a general level, we remain very much where we were with Lynch in 1990-much environmental harm is the inevitable flip-side to the capitalist ideal of growth. However, specific theoretical ideas (such as the treadmill of production; Greife and Stretesky; chapter 9), and in depth analyses of relationships between the environment and the (global) economy (such as the chapters that make up section four) build towards a far more nuanced and detailed understanding of the processes at work here. Capitalist structures, social inequality and environmental damage are intrinsically linked, and the 
various chapters in this book work together to increase our understanding of exactly how and why this is so. Again, following the point in the previous paragraph and the earlier observation about the overlap between social justice and environmental causes, we begin to see common ground between green criminology and more traditional criminological concerns.

In short, this book makes a major contribution to green criminology itself, and also to cementing green criminology within the criminological mainstream (which it can not only take from, but significantly contribute to). From the somewhat self-interested perspective of teaching green criminology to undergraduates, I thank South and Brisman on two counts. With this handbook, the case for green criminology is easier to make when confronted with students (or colleagues) who doubt the place of studying environmental harm as a core component of an undergraduate criminology course. And despite all the recent publishing activity in this area, constructing a reading list again becomes relatively straightforward: this book makes a strong claim to being at the top.

\section{References}

Lynch, M. J. (1990). The greening of criminology: A perspective on the 1990s. Critical Criminologist, 2(3), $1-4$. 